\title{
Memorial Note
}

\section{WITOLD ŻABIŃSKI}

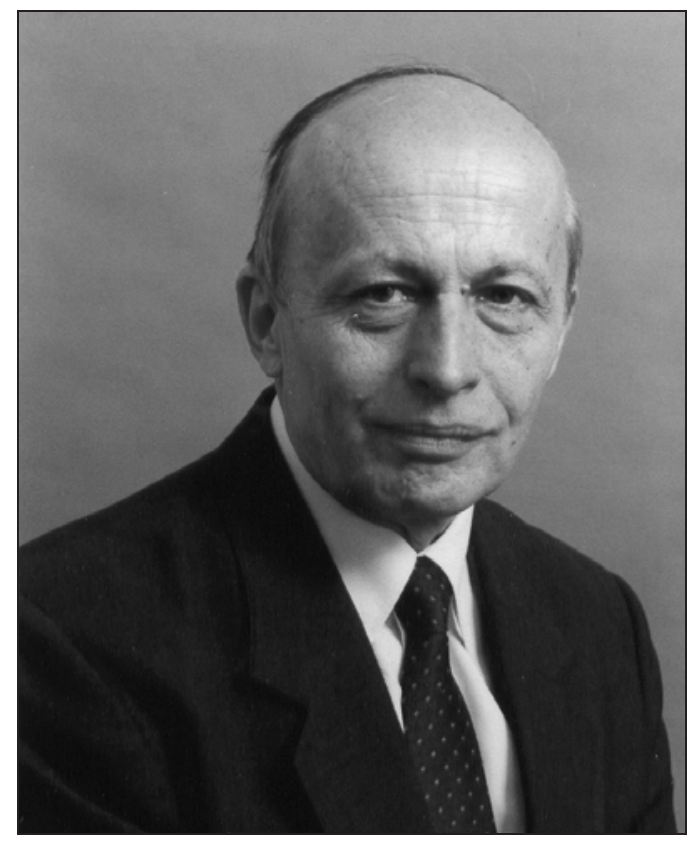

Witold Żabiński, professor emeritus of the Faculty of Geology, Geophysics and Environmental Protection at the University of Science and Technology - AGH in Cracow (Poland) passed away on $15^{\text {th }}$ January, 2007.

Witold Żabiński was born on $17^{\text {th }}$ July, 1929 in Cracow as a son of a professor and rector of the Economic University. His early interest in the natural sciences is documented in the 1947 concise book Guide Book of Cracow and its Environs, published when he was 18 years old. In the years 1947-1951 he studied geology and chemistry at the Faculty of Mathematics and Natural Sciences at the Jagiellonian University in Cracow, from which he graduated in 1951 with a Master of Philosophy degree in geology and palaeontology. In the same year he was employed as an assistant at the Department of Mineralogy and Petrography at the Academy of Mining and Metallurgy in Cracow. In the following years he climbed the academic ladder there, obtaining the posts of an adjunct (1959), associate professor
(1965) and extraordinary professor (1973). In 1981 he achieved the top academic position of the ordinary professor and in 1993 was elected a member - correspondent of the Polish Academy of Arts and Sciences. In 1966 Witold Żabiński received a scientific scholarship in Oxford (UK) under supervision of Professor Jack Zussman. In the following year he became a member of the Mineralogical Society of Great Britain and Ireland.

It is difficult to describe all the duties and professional positions of Professor Żabiński. The most important were: chairman of Mineralogy and Geochemistry Department and director of the Institute of Geology and Mineral Raw Materials at the Academy of Mining and Metallurgy, chairman and organizer of the Mineralogy Department at the University of Silesia, and chairman of the Mineralogy and Petrology Department at the Jagiellonian University in Cracow. For eight years $(1982-1990)$ he was also the Chairman of the Committee on 
Mineralogical Sciences of the Polish Academy of Sciences. Professor Żabiński was acclaimed as a devoted organizer of scientific activities for Polish mineralogists and as one of the charter members of the Mineralogical Society of Poland and its president in the years 1980-1994. He was also a year-long representative for the IMA Commission on Physics of Minerals and was an excellent editor-in-chief of its periodical Mineralogia Polonica for 34 years (1970-2004), following his earlier experience in editing Mineralogical Transactions of the Cracovian Branch of the Polish Academy of Sciences. During those years, Professor Żabiński developed a strong and fruitful cooperation with many institutions, organizations and scientific societies in Poland and abroad. Such cooperation with specialists in other branches of the mineral sciences, as well as with chemists and physicists, resulted in numerous excellent modern papers on detailed mineralogy and geochemistry of minerals and rocks, as well as in the edition of several valuable academic textbooks.

The scientific output of Witold Żabiński is contained in more than 200 publications, presented to a large extent in international periodicals. They reflect the scientific interests of the author in successive periods of activity. The first of them refer to petrology of igneous and sedimentary rocks of southern Poland. Later papers, including his $\mathrm{PhD}$ thesis (1959), are devoted to mineralogy and geochemistry of the oxidation zone in the Cracow-Silesian zinc-lead deposits, while other works deal with the synthesis of various calcium carbonates. Particularly valuable are those on zinc-bearing anhydrous and hydrated carbonate minerals. In later years he studied the silicate minerals of the hydrogarnet group and summarized his vast knowledge on the subject in the monograph Hydrogarnets, which was the basis for his habilitation in 1965. Identification of the vesuvianite varieties dispersed in some hydrogarnets, infrared spectroscopic evidence of ordering of the vesuvianite structure, the optical absorption and the presence of $\mathrm{Fe}^{3+}$ and $\mathrm{Cu}^{2+}$ ions in vesuvianite were of particular interest for Żabiński. This group of minerals, their crystallographic structure and optical features fascinated him throughout his life. He applied novel and sophisticated methods, such as infrared spectroscopy, electron paramagnetic resonance and nuclear magnetic resonance, as well as Mössbauer and Raman spectroscopies to the study of them. He also drew attention to such minerals as axinite, chrysoprase, smectites, zeolites, hydroalumo-calcite and monohydrocalcite.

The results of Witold Żabiński's investigations were published in journals such as: Mineralogical Magazine, Journal of Molecular Spectroscopy, Physics and Chemistry of Minerals, Journal of Thermal Analysis, European Journal of Mineralogy, Neues Jahrbuch für Mineralogie and Mineralogia Polonica. They were highly acclaimed in foreign scientific centres and well cited in scientific literature around the world. Some papers were presented at several Polish and international conferences, e.g. at the IMA congresses, and during his visits to foreign universities (Berlin, Cambridge, Marburg, Novosibirsk, Oxford, Orléans, Pisa, Salzburg, Toronto, Vienna). A full list of his publications is included in Mineralogia Polonica, 2007, volume $\mathbf{3 8}$, no. 1 .

Witold Żabiński was a gifted teacher. His lectures were always well prepared, understood and clearly presented. He initiated and organized the so-called 'Postgraduate Study on the Methods of studying Minerals and Rocks' at the Faculty of Geology of the Academy of Mining and Metallurgy. He was its leader and head for many years. Professor Żabiński supervised $22 \mathrm{MSc}$ theses and $13 \mathrm{PhD}$ dissertations.

Witold Żabiński is an example of an extremely reliable, precise researcher and a magnificent man. We are sure that his merits in scientific and academic activities, highly-appreciated within the Polish mineralogical community, will be long remembered not only by mineralogists in Poland but also abroad. For those of us who had a chance to meet and work with Professor Żabiński, he will always remain in our memories as a very modest man with a wonderful human personality; a person of unblemished reputation; a model scientist to be followed. BARBARA KWIECIŃSKA,
WoJCIECH NAREBSKI,
ANDRZEJ SKOWROŃSKI 